\section{Colloidal origin of microbands in banded iron formations}

\section{M.S. Egglseder ${ }^{1,2 *}$, A.R. Cruden ${ }^{1}$, A.G. Tomkins ${ }^{1}$, S.A. Wilson ${ }^{1,3}$, A.D. Langendam ${ }^{1}$}

Abstract

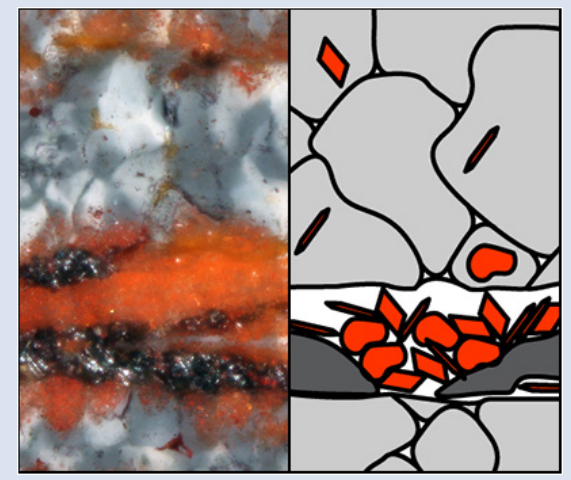

Precambrian banded iron formations record the composition of Earth's atmosphere and hydrosphere during the global rise of oxygen. It has been suggested that the banded texture of these rocks points to fluctuations in ocean chemistry although this remains a subject of debate. Here we show, by petrographic and electron microscopy of Palaeoproterozoic banded iron formations from the Hamersley Province, NW Australia, that not all iron oxide microbands represent primary sedimentary layers. Some iron oxide laminae are derived from abundant hematite particles that were originally encapsulated in chert layers and subsequently liberated by removal of quartz during post-depositional deformation by dissolution-precipitation creep. The liberated hematite particles progressively accumulated in layer-parallel aggregates forming microbands, with new hematite crystals forming via non-classical crystallisation pathways during diagenesis and metamorphism. Therefore, microbands do not necessarily correspond to fluctuations in the depositional environment.

Received 5 July 2017 | Accepted 13 February 2018 | Published 11 April 2018

\section{Introduction}

Banded iron formations (BIFs) are chemical sedimentary rocks that originated in Precambrian marine settings. BIFs are characterised by their compositional banding with thicknesses on the scales of metres, centimetres, and millimetres to micrometres, termed macrobands, mesobands, and microbands, respectively. Shale horizons separate individual BIF macrobands, which are subdivided into meso- and microbands dominated by iron oxide minerals (e.g., magnetite, hematite), iron silicates and iron carbonates, alternating with bands dominated by chert (i.e. microcrystalline quartz) (Trendall and Blockley, 1970).

The origin of the banded texture of BIFs is still controversial. The majority of models assume that iron-rich micro- and mesobands represent primary layering related to deposition of precursor iron minerals (e.g., ferrihydrite) produced by secular changes in bacterial activity (Posth et al., 2008), chemical precipitation (Garrels, 1987), hydrothermal or volcanic influx (Bekker et al., 2010), and/or re-sedimentation (Krapež et al., 2003). The origin of chert bands in BIFs is also controversial. Although it is widely acknowledged that chert layers form from amorphous silica of abiotic origin (Posth et al., 2008), it is unknown whether they form from silica deposited alongside ferric oxide precipitates (Fischer and Knoll, 2009), by seafloor silicification during depositional hiatuses (Rasmussen et al., 2015a), or below the seafloor during compaction (Krapež et al., 2003).
Alternative models interpret the banded texture of BIF as a secondary differentiation product generated during burial metamorphism by ion diffusion through a homogeneous mass of silica gel (Pecoits et al., 2009), or by differential compaction (Trendall and Blockley, 1970). The critical problem for all of these interpretations lies in establishing whether the observed mineral assemblages are of diagenetic origin and thus whether or not they can be directly related to palaeoenvironmental conditions (Bekker et al., 2010).

New nanoscale studies on 'dusty' chert bands interpreted the presence of abundant colloidal hematite as a product of early sedimentary ferrihydrite (Sun et al., 2015; Sun and Li, 2017), or post-depositional oxidation of primary iron silicates (Rasmussen et al., 2015b, 2016) (The term 'colloid' refers to a phase that has a least one dimension in the nanometre range, which is dispersed in another phase of different composition or state; i.e. here solid hematite particles dispersed in solid quartz grains). Although laboratory experiments have demonstrated that diagenetic recrystallisation of ferrihydrite to iron oxides can occur (Posth et al., 2013), no study has yet comprehensively described the role of deformation in controlling the evolution of (micro-) banding in BIFs.

Here, we investigate the fate of colloidal hematite during deformation and low temperature metamorphism to clarify the evolution of BIF banding. Our results show that post-depositional physicochemical processes have obscured primary information and may be responsible for much of the microbanding seen in these rocks.

\footnotetext{
1. School of Earth, Atmosphere and Environment, Monash University, 9 Rainforest Walk, Clayton, 3800 Victoria, Australia

2. Current affiliation: Department of Biomaterials, Max-Planck Institute of Colloids and Interfaces, Am Mühlenberg 1, 14476 Potsdam, Germany

3. Current affiliation: Department of Earth and Atmospheric Sciences, University of Alberta, Edmonton, T6G 2E3 Alberta, Canada

Corresponding author (email: egglseder.mathias@gmail.com)
} 

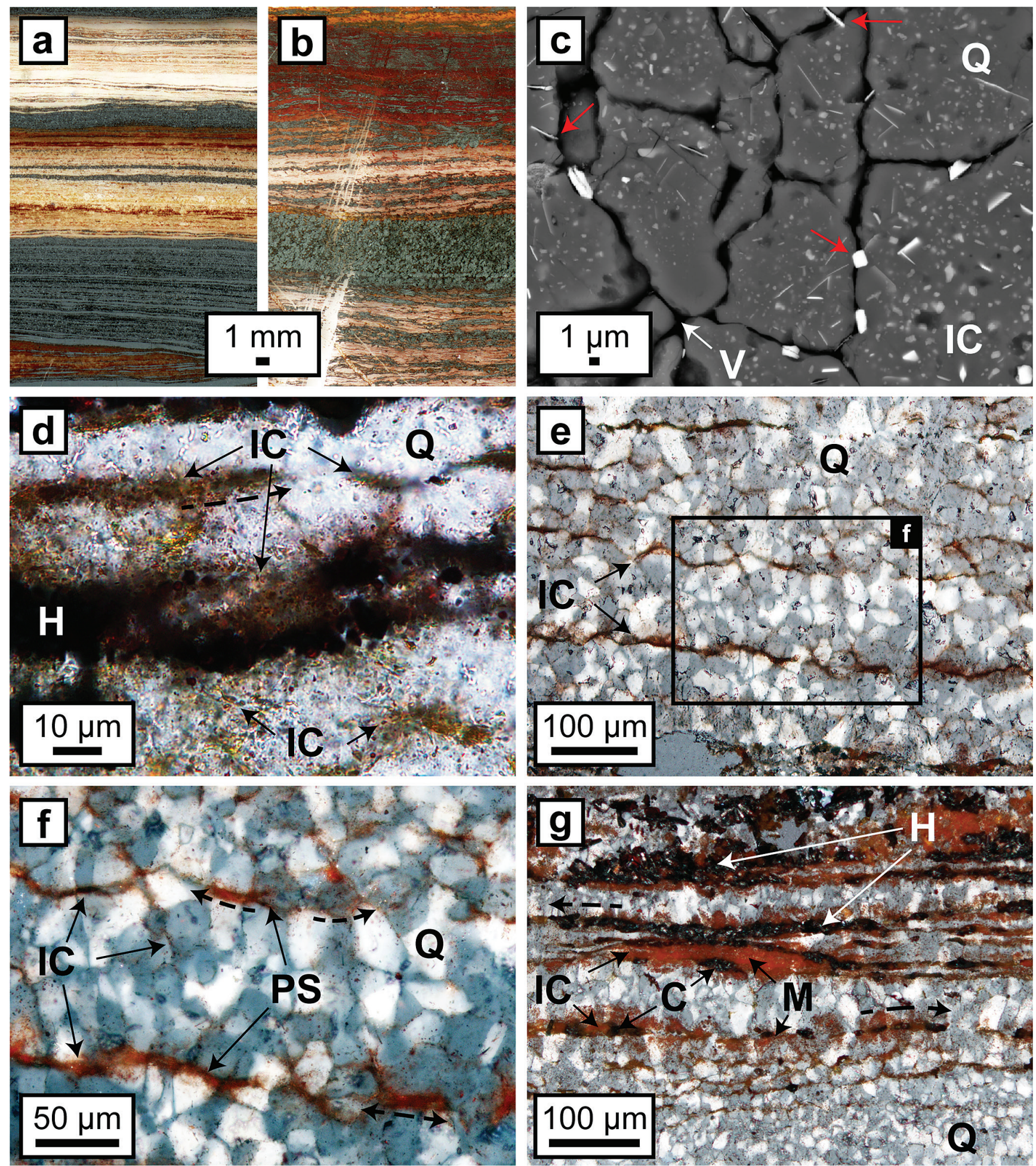

Figure $1(a, b)$ Transmitted light images (TL) of microbands of chert/quartz (white), chert with colloidal hematite (red, brown) and hematite bands (blue grey). (c) BSE image with colloidal hematite 'floating' in quartz crystals, partly liberated (red arrows) and free hematite particles at grain boundaries. (d) TL and $(e, f)$ reflected light images (XPL) displaying irregular layers of hematite particles at truncated quartz crystals (PS) and along quartz grain boundaries with lateral transitions into equigranular quartz aggregates (dashed arrows). (g) XPL image showing hematite particles that surround layered hematite forming core/mantle textures. C: core, H: hematite, M: mantle, IC: iron oxide colloids/particles, PS: pressure solution, Q: quartz, V: void.

\section{Samples and Methods}

Samples were collected from BIF outcrops of the $\sim 2.48 \mathrm{Ga}$ Dales Gorge Member, NW Australia, from the central part of the Hamersley Province (Turner Syncline), which has been affected by maximum lower greenschist facies metamorphic conditions (Smith et al., 1982; Fig. S-1). We selected samples that contain alternating chert bands with brown, orange, pink or red colours and fine- to coarse-grained iron oxide bands for scanning electron microscopy (SEM) and X-ray diffraction (XRD) analyses (Fig. 1; Supplementary Information). Polished samples for SEM observation were thoroughly washed with ultrasonic cleaners to eliminate sample preparation contaminants, although this procedure may have inadvertently removed some original particles from the rocks. 

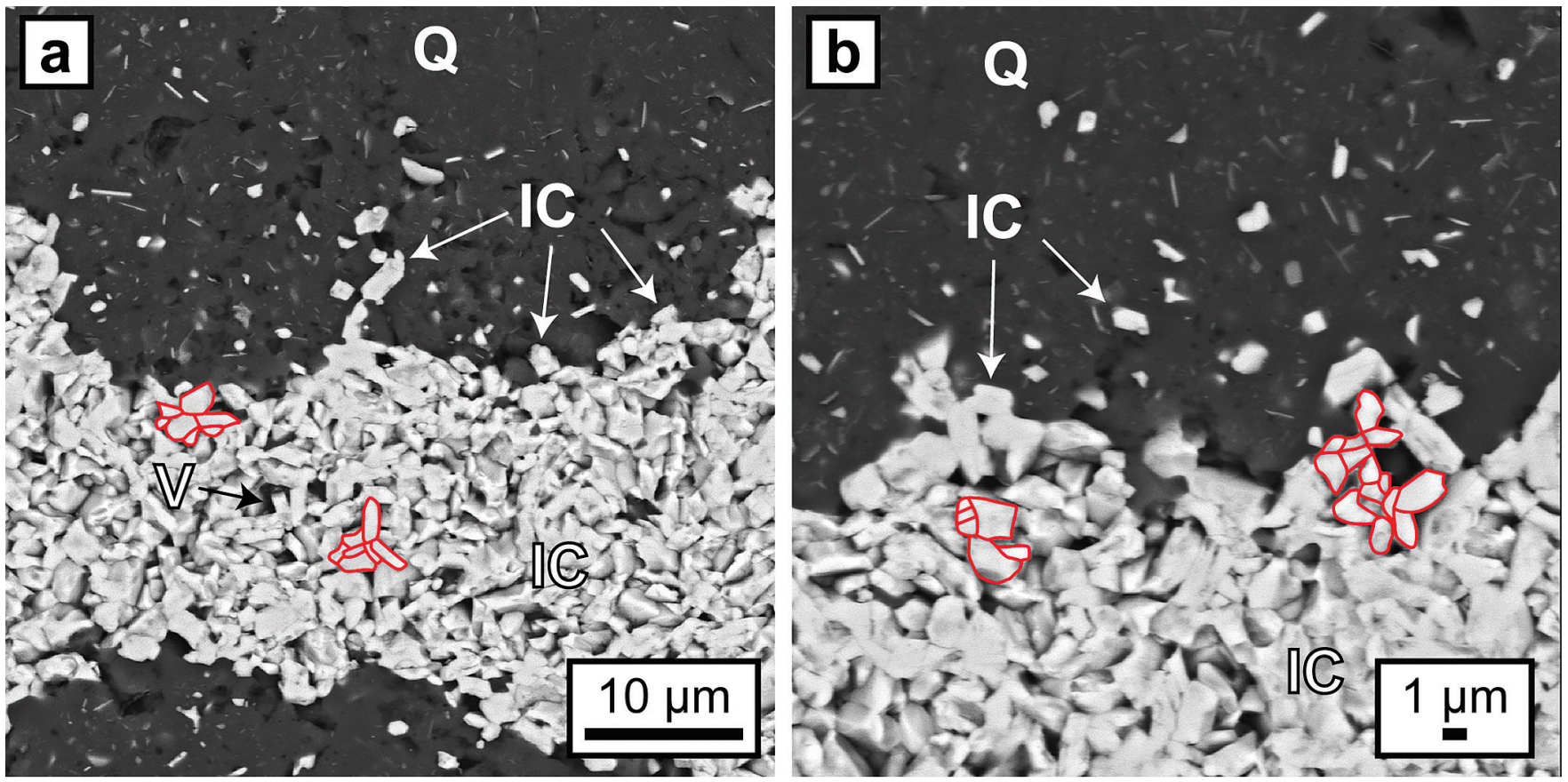

Figure 2 (a, b) BSE images of hematite particles along truncated quartz crystals forming dense aggregates (red outlines) with intergranular pores. Encapsulated colloidal hematite in chert and hematite particles in microbands show similar grain sizes and morphologies. IC: iron oxide colloids/particles, Q: quartz, V: void.

\section{Hematite Particles and Microbands}

Optical microscopy and SEM analyses show that differences in chert band colouration are caused by inclusion of varying amounts of randomly oriented subhedral to euhedral nm- to $\mu \mathrm{m}$-sized iron oxide particles within microcrystalline quartz grains (Fig. 1a-c). Particles occasionally protrude from quartz grains or occur along narrow grain boundaries (Fig. 1c). XRD analyses of coloured chert bands primarily identified highly crystalline hematite with crystallite sizes of around $100 \mathrm{~nm}$; goethite was absent or present at very low abundances $(\leq 0.5$ wt. \%). The extensive colour variation likely corresponds to differences in size and morphology of hematite particles, shifting from the characteristic red colour of macroscopic crystals to orange for sub- $\mu \mathrm{m}$-sized particles (Cornell and Schwertmann, 2003) (Fig. 1d).

On the microscale (Fig. 1e,f), accumulations of hematite particles are predominantly located along laminae of truncated quartz crystals sub-parallel to the banding. Back scattered electron (BSE) images show that hematite particles can form microbands that share highly irregular boundaries with adjacent chert layers (Fig. 2). Hematite particles in microbands are randomly oriented and have similar sizes and morphologies to the intragranular colloidal hematite encapsulated within quartz grains (Fig. 2).

Hematite particles form fine-grained coatings on pore walls and/or completely fill the available pore space. Microcrystalline quartz grains are then encapsulated by agglomerations of hematite particles which inherit the irregular shape of the quartz aggregates (Fig. 3). Colloform or vein-like crystal growths that would indicate nucleation points for hematite on pore walls were absent. Thicker layers of hematite particles commonly host larger $\mu \mathrm{m}$-sized grains of anhedral to euhedral hematite, which are commonly surrounded by a cloud or mantle of smaller hematite particles (Figs. 1g, 3a,e). Some laterally uniform bands consist almost entirely of coarsely crystalline hematite with few remaining hematite particles (Figs. 1g, 3d,e).

\section{Liberation of Colloidal Hematite}

Our observations indicate that many previously encapsulated hematite particles have been liberated from quartz, as demonstrated by their partial liberation, and the similarity in grain sizes and morphologies to fully liberated particles (Figs. 1c, 2, $3 a-c)$. The layer-parallel truncation of quartz grains indicates that quartz dissolution occurred along a systematic preferred orientation induced by deformation. The importance of dissolution-precipitation creep (DPC, or pressure solution) during deformation of BIF has recently been revealed through the observation of variably developed crystallographic preferred orientations within alternating chert bands (Egglseder et al., 2016).

DPC is induced by stress applied to a fluid-bearing polymineralic aggregate where quartz dissolves in fluid at grain boundaries and aqueous silica is subsequently transported by diffusion to precipitate in areas of lower concentration (Bons and den Brok, 2000). This process ultimately leads to intercalation of strongly oriented secondary quartz and more pristine chert layers that lack preferred orientation (Egglseder et al., 2016) (Fig. S-2). DPC can commence at pressures as low as $2-3$ bar and it is influenced by electrochemical potential differences between dissimilar minerals such as mineral inclusions (colloidal phases) within quartz (Greene et al., 2009).

\section{Transport of Particles}

We interpret that the small size of hematite particles allowed them to be transported through the micro-porosity of the BIF, which promoted the development of layer-parallel hematite particle accumulations (Fig. 3a-c). Once quartz was removed by DPC, the liberated particles could have: 1) accumulated in situ (Figs. 1d-g, 2), 2) been transported into connected pore spaces creating porosity-infilling textures (Figs. 3a-c); or 3) been dissolved in the available fluid phase. The latter process is not evident in our samples, as the size and shape of the particles inside and outside quartz grains are not 

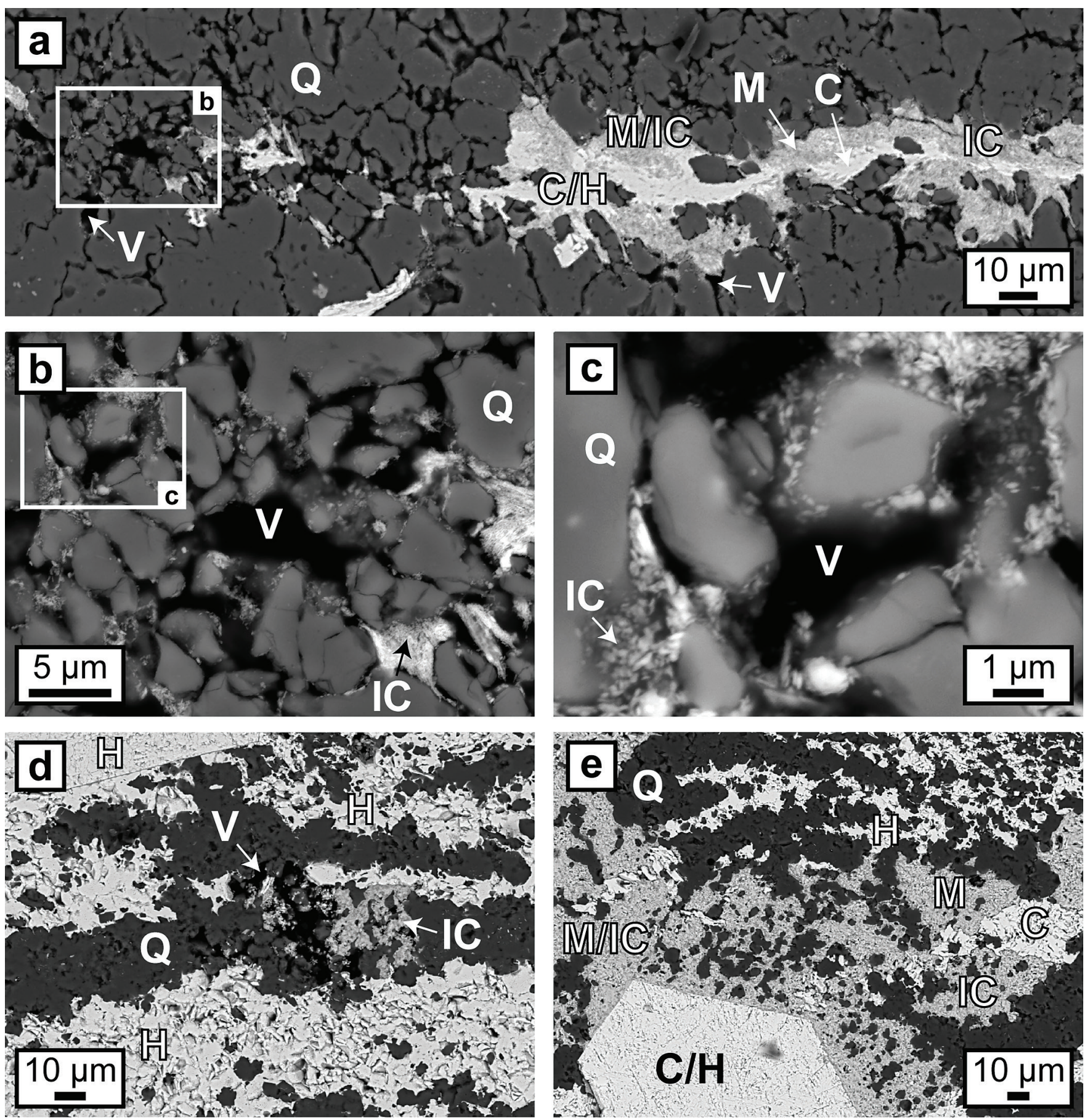

Figure 3 (a-e) BSE images of BIF laminae illustrating the lateral change from porous chert to hematite microbands with irregular boundaries. $(\mathbf{a}-\mathbf{c})$ The porosity is (partly) filled with hematite particles encapsulating quartz grains. (d-e) Hematite forms more larger crystals inside these particle agglomerations, as evident by core/mantle structures resulting in new microbands of hematite. C: core, $\mathrm{H}$ : hematite, M: mantle, IC: iron oxide colloids/particles, Q: quartz, V: void.

significantly different. The lack of evidence for hematite precipitation also suggests that extensive dissolution of liberated particles is unlikely to have occurred. We suggest that the liberated hematite particles in our samples behaved similarly to colloidal dispersions, in that their transport was controlled by the fluid flow velocity and physicochemical interactions among particles, the porous medium, and the fluid (Tosco et al., 2012).

\section{Transformation of Particles}

Transported hematite particles appear to have been transformed into larger hematite crystals (Figs. 2, 3a,d,e). Previous studies suggested that this transformation occurred by dehydration of ferrihydrite (Posth et al., 2013) or dissolution-precipitation (Ostwald ripening) (Sun et al., 2015). In these cases, larger crystals grow at the expense of smaller crystals by dissolution of the particles within a suitable fluid followed by precipitation of the dissolved ions on an existing nucleus, which eventually leads to the formation of relatively smooth, defect-free crystals (Cölfen and Antonietti, 2008). Alternatively, we propose that the large hematite crystals formed predominantly by attachment of previously encapsulated particles (Figs. 1 to 3).

The self-assembly of particles and their consequent transformation to larger crystals is a common mechanism of non-classical crystallisation (Penn and Banfield, 1998). This 


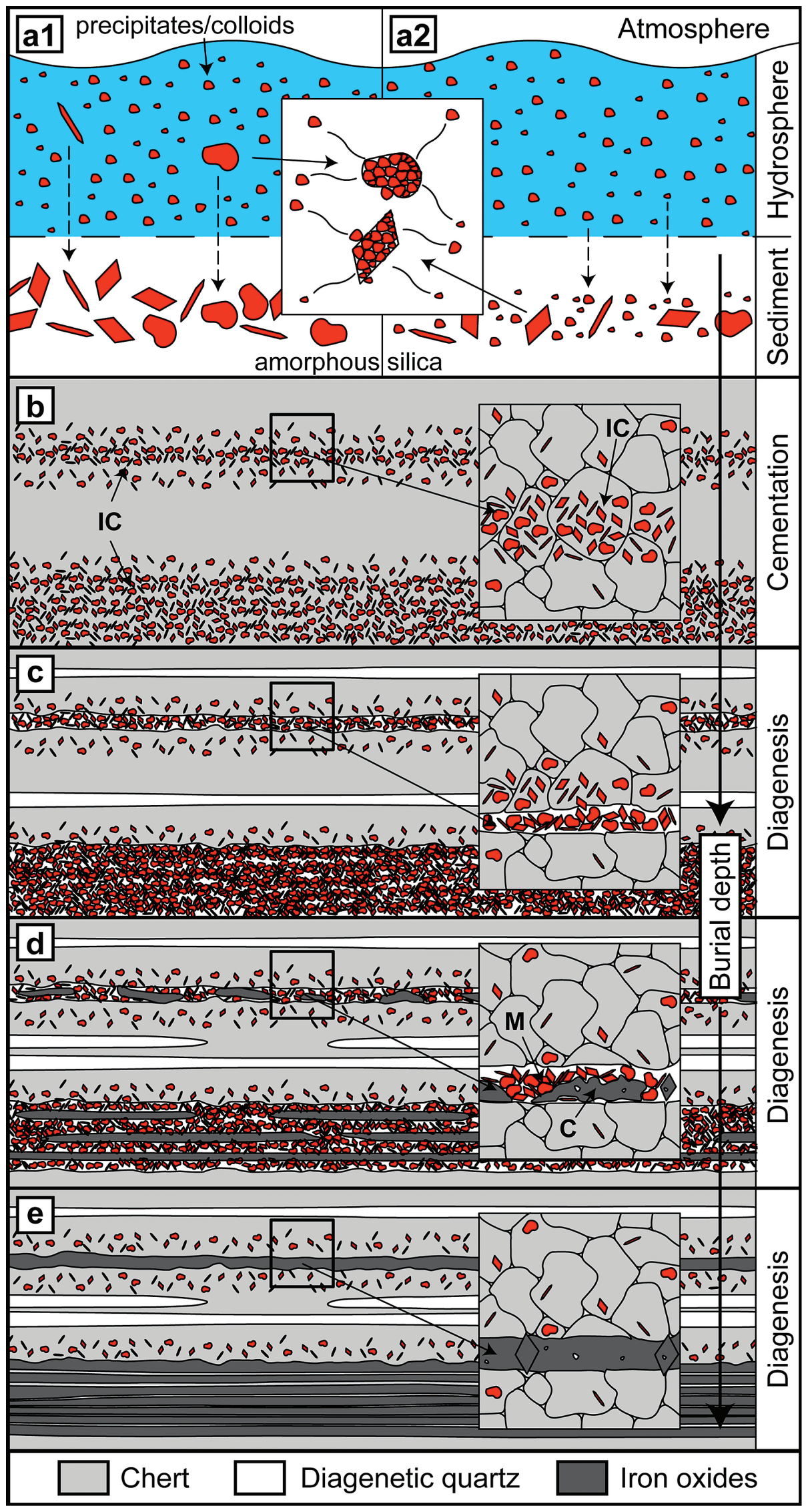

Figure 4 Conceptual evolution from BIF precursor sediments to BIF microbands. (a1, a2). Schematic Precambrian depositional environment of BIF precursor minerals. The inset shows the aggregation of precipitates/colloidal phases to form larger particles by flocculation in the water column (a1) and/or attachment in the sediment prior to lithification (a2). (b-e) Development of BIF textures after lithification. Insets show the microscale to nanoscale formation of minerals and textures. (b) Quartz crystallisation (cementation) leads to the entrapment of randomly dispersed colloidal phases. (c) Progressive compression leads to quartz dissolution by DPC, liberation of encapsulated particles and residual layer-parallel accumulation. Dissolved silica forms new particle-free quartz layers (i.e. diagenetic quartz). (d) Simultaneously, accumulated particles transform into more stable iron oxides resulting in the common BIF texture of pristine chert, diagenetic quartz and iron oxide microbands (e). 
behaviour is common to iron oxide particles and has found wide applications in environmental science, material science, and nanotechnology (Guo and Barnard, 2013), but has not yet been applied to BIFs. Penn and Banfield (1998) found small misorientations across the interfaces of larger crystals formed by particle attachment, which cannot be explained by classical crystallisation via dissolution-precipitation reactions. Such dislocations have been previously identified using transmission electron microscopy (TEM) within goethite (Morris, 1985) and hematite crystals (e.g., Sun et al., 2015) in BIFs (images reproduced in Figs. S-3 to S-5). However, these features have not previously been recognised for what they are: textural evidence that non-classical crystallisation plays a role in forming microbands in BIF. Crystal growth by particle aggregation also forms anhedral to euhedral crystals, mineral twinning, defects, and nano- to micro-porosity (Guo and Barnard, 2013) of the sort observed in our samples (Fig. 3d).

This solid-state process of non-classical crystallisation can be facilitated by internal rearrangements, dehydration, reduction/oxidation, and topotactic transformations until the components (e.g., hematite particles) are exhausted (Cölfen and Antonietti, 2008; Faivre, 2016). However, the transformation pathway is sensitive to the environmental conditions (e.g., $\mathrm{T}$, $\mathrm{pH}$, ionic strength) and the precursor material, both of which control the mineralogy and morphology of the final crystals (Guo and Barnard, 2013). In principle, non-classical crystallisation can be combined with classical crystallisation mechanisms (Faivre, 2016), creating complex pathways for formation of the common hematite and magnetite end products seen in BIF.

\section{Implications for BIF Formation}

The initial precipitation of BIF precursor minerals in the ancient oceans was likely controlled by environmental changes in the depositional environment (Bekker et al., 2010). Depending on ambient conditions, iron-bearing precipitates would have remained in suspension until they flocculated and deposited on the seafloor forming thin beds (Fig. 4a1) concomitant or alternating with amorphous silica deposition (Posth et al., 2008). Flocculation could have involved particle aggregation of the sort observed in previous studies (Morris, 1985; Sun et al., 2015) (Fig. 4a1). Alternatively, iron-bearing precipitates may have initially bonded to silica prior to their deposition (Fig. 4a2) (Fischer and Knoll, 2009). Both phases could have separated again after deposition to form amorphous silica and iron-bearing colloidal solids, which agglomerated into larger particles (Fig. 4a2). Both routes are not mutually exclusive and the unconsolidated sediments would have been susceptible to reworking by density currents or other sedimentary processes.

Subsequent compaction would have led to dehydration of amorphous silica to form microcrystalline quartz, resulting in chert layers containing variable amounts of iron-rich particles (Fig. 4b). Because DPC is enhanced by impurities, diagenesis and deformation likely promoted preferential DPC within chert layers with higher mineral inclusion content (Fig. 4b,c) (Greene et al., 2009), creating a banding effect. The release of particles from the chert layers during DPC would have led to residual agglomeration of particles or transport by fluids within pore networks and their concentration into chert and iron oxide microbands (Figs. 1a, 2, 4c). In combination, these processes are expected to obscure primary depositional textures.
Aggregation of particles by progressive particle attachment can account for the formation of bands dominated by larger hematite or magnetite crystals (Fig. 4d). Remobilised quartz could have escaped the system by diffusion, or have formed new diagenetic quartz bands such as those observed in our study (Figs. 4c-e, S-2), which are virtually particle-free and possess strong crystallographic preferred orientations, characteristic of quartz formed by DPC (Egglseder et al., 2016).

Ongoing segregation led to the enhancement of microbands, possibly including removal of thin chert bands to form iron oxide mesobands (Fig. 1a) (Trendall and Blockley, 1970). Although our observations do not exclude the possibility that mesobands formed by primary deposition, we suggest that the processes of particle liberation and non-classical crystallisation enhanced primary layering because initial variations in iron oxide particle concentration within microcrystalline quartz control the post-depositional segregation process. Hence, chemical signals of the Precambrian oceans and Earth's early biosphere deduced from microbands and possibly mesobands of BIFs have likely been obscured by diagenetic processes; thus, new studies are necessary that integrate physical and chemical post-depositional phenomena to better constrain their effects on geochemical records preserved by BIFs.

\section{Acknowledgements}

We are grateful to Hilke Dalstra (RioTinto Exploration Ltd), Leigh Nicholas and Jim Gordon and their teams (RioTinto Iron Ore Ltd) for their abundant and helpful support. M.S.E. and A.R.C. also acknowledge Monash University for scholarship and research support, respectively. M.S.E. is grateful to Andrea Rielli and Marianne Richter (both Monash University) for assistance with SEM imaging. We thank Nathan Webster, CSIRO Mineral Processing, for his generous help with XRD data collection. We are grateful to Paul Bons, Ariel Anbar and an anonymous reviewer for their helpful comments.

Editor: Ariel Anbar

\section{Additional Information}

Supplementary Information accompanies this letter at http:// www.geochemicalperspectivesletters.org/article1808.

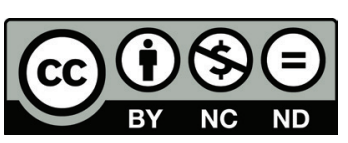

This work is distributed under the Creative Commons Attribution Non-Commercial No-Derivatives 4.0 License, which permits unrestricted distribution provided the original author and source are credited. The material may not be adapted (remixed, transformed or built upon) or used for commercial purposes without written permission from the author. Additional information is available at http://www.geochemicalperspectivesletters.org/ copyright-and-permissions.

Cite this letter as: Egglseder, M.S., Cruden, A.R., Tomkins, A.G., Wilson, S.A., Langendam, A.D. (2018) Colloidal origin of microbands in banded iron formations. Geochem. Persp. Let. $6,43-49$. 


\section{References}

Bekker, A., Slack, J.F., Planavsky, N., Krapež, B., Hofmann, A., Konhauser, K.O., RouxeL, O.J. (2010) Iron Formation: The Sedimentary Product of a Complex Interplay among Mantle, Tectonic Oceanic, and Biospheric Processes. Economic Geology 105, 467-508.

BONS, P.D., DEN BROK, B. (2000) Crystallographic preferred orientation development by dissolution-precipitation creep. Journal of Structural Geology $22,1713-1722$.

Cölfen, H., Antonietti, M. (2008) Mesocrystals and Nonclassical Crystallization. John Wiley and Sons, Chichester.

CORNELL, R.M., SCHWERTMANN, U. (2003) The iron oxides - structure, properties, reactions, occurences and uses. Wiley-VCH, Weinheim.

EgGlseder, M.S., CRUden, A.R., TOMKINS, A.G., Wilson, C.J.L. (2016) Deformation-induced silica redistribution in banded iron formation Hamersley Province, Australia. Lithos 266-267, 87-97.

FAIVRE, D. (2016) Iron oxides - from nature to applications. Wiley-VCH, Weinheim.

FischeR, W.W., KNOLL, A.H. (2009) An iron shuttle for deepwater silica in Late Archean and early Paleoproterozoic iron formation. Geological Society of America Bulletin 121, 222-235.

GARRELS, R.M. (1987) A model for the deposition of the microbanded Precambrian iron formations. American Journal of Science 287, 81-106.

Greene, G.W., Kristiansen, K., Meyer, E.E., Boles, J.R., IsraelachVILI, J.N. (2009) Role of electrochemical reactions in pressure solution. Geochimica et Cosmochimica Acta 73, 2862-2874.

GUO, H., BARNARD, A.S. (2013) Naturally occurring iron oxide nanoparticles: morphology, surface chemistry and environmental stability. Journal of Materials Chemistry A 1, 27-42

KRAPEŽ, B., BARLEY, M.E., PicKARD, A.L. (2003) Hydrothermal and resedimented origins of the precursor sediments to banded iron formation sedimentological evidence from the Early Palaeoproterozoic Brockman Supersequence of Western Australia. Sedimentology 50, 979-1011.

MORRIS, R.C. (1985) Genesis of iron ore in banded iron-formation by supergene and supergene-metamorphic processes - a conceptual model. In Wolf, K.H. (Ed.) Handbook of Strata-Bound and Stratiform Ore Deposits. Elsevier, Amsterdam, 73-235.

Pecoits, E., Gingras, M.K., Barley, M.E., Kappler, A., Posth, N.R. KONHAUSER, K.O. (2009) Petrography and geochemistry of the Dales Gorge banded iron formation: Paragenetic sequence, source and implications for palaeo-ocean chemistry. Precambrian Research 172, 163-187.

PenN, R.L., Banfield, J.F. (1998) Imperfect Oriented Attachment: Dislocation Generation in Defect-Free Nanocrystals. Science 281, 969-971.

Posth, N.R., Hegler, F., Konhauser, K.O., Kappler, A. (2008) Alternating $\mathrm{Si}$ and $\mathrm{Fe}$ deposition caused by temperature fluctuations in Precambrian oceans. Nature Geoscience 1, 703-708.

Posth, N.R., KonHAuser, K., KappleR, A. (2013) Simulating Precambrian banded iron formation diagenesis. Chemical Geology 362, 66-73.

Rasmussen, B., KrapeŽ, B., Muhling, J.R. (2015a) Seafloor silicification and hardground development during deposition of $2.5 \mathrm{Ga}$ banded iron formations. Geology 43, 235-238.

Rasmussen, B., Krapež, B., Muhling, J.R., Suvorova, A. (2015b) Precipitation of iron silicate nanoparticles in early Precambrian oceans marks Earth's first iron age. Geology 43, 303-306.

Rasmussen, B., Muhling, J.R., Suvorova, A., Krapez, B. (2016) Dust to dust: Evidence for the formation of "primary" hematite dust in banded iron formations via oxidation of iron silicate nanoparticles. Precambrian Research 284, 49-63.

SMith, R.E., Perdrix, J.L., PARKS, T.C. (1982) Burial metamorphism in the Hamersley basin, Western Australia. Journal of Petrology 23, 75-102.

SUN, S, LI, Y.-L. (2017) Geneses and evolutions of iron-bearing minerals in banded iron formations of $>3760$ to ca. 2200 million-year-old: Constraints from electron microscopic, $\mathrm{X}$-ray diffraction and Mössbauer spectroscopic investigations. Precambrian Research 289, 1-17.

Sun, S., Konhauser, K.O., Kappler, A., LI, Y. (2015) Primary hematite in Neoarchean to Paleoproterozoic oceans. Geological Society of America Bulletin 127, 850-861.

Tosco, T., Bosch, J., Meckenstock, R.U., Sethi, R. (2012) Transport of Ferrihydrite Nanoparticles in Saturated Porous Media: Role of Ionic Strength and Flow Rate. Environmental Science and Technology 46, 4008-4015.

Trendall, A.F., Blockley, J.G. (1970) The iron formations of the Precambrian Hamersley Group, Western Australia: Geological Survey of Wester Australia Bulletin 119. Geological Survey of Western Australia, Perth. 